\title{
Duckweeds: their utilization, metabolites and cultivation
}

\author{
GahYoung Baek, Maham Saeed and Hyung-Kyoon Choi*
}

\begin{abstract}
Duckweeds are floating plants of the family Lemnaceae, comprising 5 genera and 36 species. They typically live in ponds or lakes and are found worldwide, except the polar regions. There are two duckweed subfamilies - namely Lemnoidea and Wolffioideae, with 15 and 21 species, respectively. Additionally, they have characteristic reproduction methods. Several metabolites have also been reported in various duckweeds. Duckweeds have a wide range of adaptive capabilities and are particularly suitable for experiments requiring high productivity because of their speedy growth and reproduction rates. Duckweeds have been studied for their use as food/feed resources and pharmaceuticals, as well as for phytoremediation and industrial applications. Because there are numerous duckweed species, culture conditions should be optimized for industrial applications. Here, we review and summarize studies on duckweed species and their utilization, metabolites, and cultivation methods to support the extended application of duckweeds in future.
\end{abstract}

Keywords: Duckweed, Utilization, Metabolite, Cultivation method

\section{Introduction}

Duckweeds are among the smallest free-floating aquatic plants worldwide. They have a simple morphology, comprising a few fronds; furthermore, they rarely flower $[1$, 2]. Duckweeds replicate and proliferate rapidly. The reproduction period is only 1.2 days per generation [3]. Additionally, they are highly adaptable and occur in diverse aquatic environments [4]. Similar to other aquatic plants, duckweed species generally inhabit the natural environment, such as ponds and lakes, and grow best especially in tropical and temperate regions [5, 6]. They can also grow well in local and industrial wastewater $[7,8]$. Because of these features, duckweeds are suitable for various experimental and practical applications that require fast and high productivity.

Duckweeds have been utilized for food, pharmaceutical, phytoremediation, and other industrial applications [9-12]. Climate crisis has become a serious problem

\footnotetext{
*Correspondence: hykychoi@cau.ac.kr

College of Pharmacy, Chung-Ang University, Seoul 06974, Republic of Korea
}

that threatens the food and feed supply of the increasing population of the world. It is known that duckweeds contain essential nutrients such as proteins, carbohydrates, and fats. Additionally, they contain a variety of secondary metabolites that are beneficial to humans. Therefore, consideration of cultivation methods of duckweeds is vital to their enhanced utilization in various industrial applications. There have been several reports regarding utilization, metabolites, and cultivation of duckweeds; these should be reviewed and summarized as a fundamental information for enhanced duckweed application. The objective of this review was to summarize the diverse utilization of duckweeds and their metabolites and cultivation methods. This review will be useful for further industrial applications of duckweeds.

\section{Duckweeds and their utilization \\ Duckweed species}

Duckweeds belong to the family Lemnaceae, comprising 5 genera and 36 species under two subfamilies Lemnoidea (15 species) and Wolffioideae (21 species) [13, 14]. Duckweed species self-replicate genetically identical clones 
in a vegetative manner, wherein daughter fronds sprout from the mother fronds $[4,15]$. However, the two subfamilies differ in how they multiply. Lemnoidea (genera Landoltia, Lemna, and Spirodela) has two meristematic regions in the mother frond. In contrast, Wolffioideae (genera Wolffia and Wolffiella) has a single meristematic pouch in the mother frond $[16,17]$. Landoltia, formerly Spirodela punctata, is a duckweed with two attached fronds [18, 19]. Lemna has one root and two to four fronds, and its length has been reported as up to $6.0 \mathrm{~mm}$ $[18,20]$. Spirodela, which has the smallest genome among the duckweed family, has five large fronds from 4 to $12 \mathrm{~mm}$ in length $[21,22]$. Wolffia is the most derived and smallest genus, which seldom exceeds 0.5 to $1.2 \mathrm{~mm}$ in length and 0.4 to $1.0 \mathrm{~mm}$ in width [17]. Wolffiella has a low flowering frequency and ranges from 1.0 to $5.0 \mathrm{~mm}$ in frond length $[16,23]$. We found that duckweed species have different morphological characteristics.

The single species of Landoltia-Landoltia punctatawas formerly Spirodela punctata [18]. The 12 species of Lemna include Lemna aequinoctialis, Lemna disperma, Lemna gibba, Lemna japonica, Lemna minor, Lemna minuta, Lemna obscura, Lemna perpusilla, Lemna tenera, Lemna trisulca, Lemna turionifera, and Lemna valdiviana. There are two Spirodela species (Spirodela intermedia and Spirodela polyrrhiza) [1]. Wolffia includes 11 species: Wolffia angusta, Wolffia arrhiza, Wolffia australiana, Wolffia borealis, Wolffia brasiliensis, Wolffia columbiana, Wolffia cylindracea, Wolffia elongata, Wolffia globosa, Wolffia microscopica, and Wolffia neglecta [24]. The 10 species of Wolffiella include Wolffiella caudata, Wolffiella denticulata, Wolffiella gladiata, Wolffiella hyalina, Wolffiella lingulata, Wolffiella neotropica, Wolffiella oblonga, Wolffiella repanda, Wolffiella rotunda, and Wolffiella welwitschii [1]. Hereafter, Lemna, Spirodela, and Wolffia genera are abbreviated as L., S., and $W$., respectively.

\section{Food and feed resources}

It is known that most duckweeds proliferate rapidly, and the harvested yield per area is higher than the average of the major crop yields [4]. The protein production of duckweeds per harvested area was higher than that of soybean, rice, and corn; thus, it could solve the problem of farmland shortage to produce food or animal feed [2528]. Duckweeds contain starch, fatty acid, protein, and other secondary metabolites used in food and feed industries [7, 9, 29-32]. Compared with red meat, plant-based foods have less of an association with cardiometabolic risks and diabetes [33, 34]. Additionally, duckweeds have been accepted as food resources without public aversion [35]. Because of their high yield, economic advantage, nutrient composition, and positive perception by people, duckweeds have been utilized as the plant-derived food and feed resources.

Table 1 lists duckweed species used as food resources. Wolffia species have long been consumed as protein sources by humans in Asia [9, 29, 36]. Currently, duckweeds are mainly consumed as amino acid supplements [29]. Parabel, Ltd. has a product line of duckweed plant powders as an alternative to high protein foods [37, 38]. Duckweeds are also expected to occur in the European food market [39]. Consumption of plant protein, instead of animal protein, is expected to reduce energy use and greenhouse gases [40]. Duckweeds are good candidates for nutritious and safe meat protein substitutes for humans. Consumption of W. globosa as a meat substitute reduces the risk of iron deficiency while maintaining iron

Table 1 List of duckweeds used as food and feed resources

\begin{tabular}{|c|c|c|}
\hline Usages & Species & References \\
\hline \multicolumn{3}{|l|}{ Food } \\
\hline Amino acid supplement & W. globosa & [29] \\
\hline Iron source & W. globosa & {$[41]$} \\
\hline Protein powder & Lemna spp. & {$[37]$} \\
\hline Tradition food & W. arrhiza and W. globosa & {$[9,29,36]$} \\
\hline Vitamin $B_{12}$ supplement & W. globosa & [29] \\
\hline \multicolumn{3}{|l|}{ Feed } \\
\hline Cattle & Lemna spp., Spirodela spp., and Wolffia spp. & {$[48]$} \\
\hline Chicken & Landoltia punctata and L. gibba & {$[7,15,26,51]$} \\
\hline Fish & L. gibba, L. minor, L. perpusilla, and S. polyrrhiza & {$[27,46,47,52]$} \\
\hline Sheep & Landoltia punctata & [49] \\
\hline Recycled feed supplement & L. minuta & {$[45]$} \\
\hline Waterfowl & L. minor & {$[50]$} \\
\hline
\end{tabular}

L. Lemna, S. Spirodela, $W$. Wolffia 
homeostasis and folic acid concentration [41]. Clinical nutrition studies have demonstrated that the essential amino acids and vitamin $B_{12}$ contents of duckweeds are comparable to peas and cheese [29]. Iron and zinc in duckweeds are sufficient for the recommended allowance, similar to the sodium/potassium ratio and fiber content [42]. The amino acid composition of Wolffia sp. and Wolffiella sp. meets the World Health Organization (WHO) recommendations $[9,43]$. The ratio of omega-3 to omega-6 fatty acids in Landoltia punctata, L. gibba, L. minor, S. polyrrhiza, W. microscopica, and Wolffiella hyalina makes them suitable for food and feed [9]. However, it should be noted that consumption of duckweed species high in oxalic acid could cause kidney stones [44]. Moreover, intake of duckweed with substance adsorption abilities could lead to heavy metal intake.

Duckweed species have been used as livestock feed for hundreds of years and have been shown to be nutritious $[15,28,31]$. Duckweed feed can supply animals with phosphate and nitrogen [39]. L. minuta can be recycled as a feed supplement by adsorbing micronutrients such as selenium and zinc, which are essential for animals [45]. W. arrhiza, used as animal feed, yields protein content comparable to that by soybeans [17]. As listed in Table 1, duckweeds are used as feed for various livestock, including cattle, chicken, fish, sheep, and waterfowl $[7,15,26$, 27, 46-51]. L. minor and S. polyrrhiza are economically viable alternatives to fish and soybean meal feed for fish and waterfowl $[27,46,50,52]$. In cows, there is no abnormality in the digestion of dry matter and crude protein of duckweed; thus, it could be used as an alternative feed for soybean meal [48]. Soybeans are most commonly used as feed, but the expansion of cultivation because of increased demand could emit significant greenhouse gases from land use change [53]. Duckweeds are considered as novel ingredients to replace soybeans, thus reducing the burden of greenhouse gas emissions and alleviating the negative aspects of feed production [51]. The protein content of duckweeds grown in organic manure is very high, and utilization of duckweed as feed has been suggested as a solution to environmental issues related to manure purification and feed production [54]. Duckweeds are protein sources that could replace soybean meal and are expected to be used as substitutes to reduce environmental pollution created by expanding soybean cultivation.

\section{Pharmaceutical resources}

As represented in Table 2, duckweeds have been suggested as pharmaceutical resources. Previous studies have been reported that duckweed species such as $L$. minor, L. trisulca, and S. polyrrhiza have been widely utilized as folk medicine in China, Korea and a few European nations [12, 44, 55]. Duckweeds are medicinal herbs that do not have severe side effect [44]. Recent research has revealed the various pharmacological effects of duckweeds. L. minor has antibacterial activity against gram-negative bacilli (Pseudomonas fluorescens, Shigella flexneri, Escherichia coli, and Salmonella typhi) and gram-positive bacteria (Bacillus subtilis), and could

Table 2 List of duckweeds used as pharmaceutical resources

\begin{tabular}{|c|c|c|}
\hline Pharmaceutical activities & Species & References \\
\hline Antibacterial activity & L. minor and S. polyrrhiza & {$[44,56-58]$} \\
\hline Anticancer activity & Landoltia punctata & [59] \\
\hline Anti-adipogenic effect & S. polyrrhiza & [61] \\
\hline Antifungal activity & L. aequinoctialis and S. polyrrhiza & {$[58,69]$} \\
\hline Antigen expression for vaccines after nuclear transformation & L.minor & [66] \\
\hline Antioxidant activity & $\begin{array}{l}\text { Landoltia punctata, L. gibba, L. minor, S. polyrrhiza, W. } \\
\text { borealis, and Wolffiella caudata }\end{array}$ & {$[44,59]$} \\
\hline Colonic health improvement & Landoltia punctata & [62] \\
\hline Cytotoxic activity & L.minor & [44] \\
\hline $\begin{array}{l}\text { Folk medicine (antiscorbutic, asthma, colds, diabetes, diuretic, febrifuge, general } \\
\text { tonic, hives, measles, edema, rhinitis, soporific, and vitiligo) }\end{array}$ & L.minor & {$[12,44]$} \\
\hline Folk medicine (choleretic and phytoncidic activities) & L. trisulca & [12] \\
\hline Folk medicine (erysipelas and leprosy) & S. polyrrhiza & [12] \\
\hline Immunomodulatory activity & L.minor & {$[57,60]$} \\
\hline Monoclonal antibody production as a transgenic plant by LEX System & L.minor & {$[63,64]$} \\
\hline Monoclonal antibody production for non-Hodgkin's lymphoma & L.minor & {$[67,68]$} \\
\hline Recombinant human granulocyte colony-stimulating factor production & W. arrhiza & [65] \\
\hline
\end{tabular}

L. Lemna, S. Spirodela, W. Wolffia, LEX System Lemna Expression System 
be an alternative to antibacterial agents for the treatment of various diseases [44, 56, 57]. S. polyrrhiza also showed antimicrobial activities against seven gram-negative bacilli, one gram-positive bacterium, and two fungal pathogens [58]. Flavonoids in duckweeds could contribute metabolites for the antioxidant activity [59]. Apigenin and vitexin in Landoltia punctata have been suggested as constituents for treating non-small lung cancer [59]. $L$. minor has been shown to have immunomodulatory activity [57]. In particular, flavonoids in L. minor have been reported to have immunosuppressive effects by reducing free hemoglobin content and antibody production in human whole blood samples infected with ovalbumin antigen [60]. Flavonoids in S. polyrrhiza have been demonstrated to exert anti-adipogenic effect by reducing triglyceride content [61]. An increase in fecal butyric acid has been reported as a result of duckweed consumption, which may be associated with improved colon health in humans and is an important energy source for colon cells [62]. Although further research and clinical trials are required for practical use, duckweeds have great potential to be utilized for pharmaceutical purposes because of their diverse pharmacological effects.

Another pharmacological potential of duckweeds is their use as a platform for human therapeutic proteins production. Recombinant therapeutic proteins are produced by Lemna Expression System (LEX System) [63, 64]. Additionally, nuclear-transformed W. arrhiza expresses human granulocyte colony-stimulating factor [65]. Nuclear-transformed L. minor-based expression studies for avian influenza vaccine development have shown the potential of transgenic duckweed to provide good-quality antigens for vaccine development [66]. Synthon/Biolex Therapeutics produces large quantities of antibodies for non-Hodgkin's lymphoma using duckweed species $[67,68]$. Duckweed-based antibody production could be considerably inexpensive and could provide easy to scale up platforms for diverse antibody-based therapies to treat and prevent diseases.

\section{Phytoremediation resources}

Duckweeds, tolerant to extreme conditions, are known as effective remediation resources for pollutants in wastewater. They purify sewage through the powerful accumulation of chemicals by adsorption or uptake $[25,70,71]$.

As listed in Table 3, duckweeds have been reported to purify inorganic, organic, and pharmaceutical materials. Ammonium elimination is necessary for the purification of wastewater because ammonium increases eutrophication in ponds and forms nitrates in groundwater [72]. Landoltia punctata absorbs ammonium from water and stores ammonium ions as a useful nitrogen source [19, 73]. Excessive concentration of boron, a by-product of industrial production, is detrimental to the ecosystem. L. gibba has also been reported to remove boron from water $[11,74]$. Boron is adsorbed to apiogalacturonans in the cell wall of duckweeds [75]. L. minor captures iron, $L$. gibba captures sulfate, and S. polyrrhiza captures fluoride [76-78].

Nitrogen and phosphorous emissions from manure in livestock systems contribute to eutrophication of ecosystems; thus, their recovery and reuse are significant and essential tasks [79]. For example, Landoltia punctata, L. gibba, L. minuta, L. turionifera, S. polyrrhiza, and W. borealis purify wastewater or swine lagoons by removing nitrogen and phosphorous [19, 70, 71, 76, 79-81]. The adsorption capacity of nitrogen and phosphorus is especially valuable because duckweeds can be reused as fertilizers that release nitrogen and phosphorus in the soil [82].

Duckweeds are resistant to several heavy metals and can be used for bioremediation in local and industrial wastewater by accumulating heavy metals, including arsenic, cadmium, chromium, cobalt, copper, lead, nickel, selenium, and zinc [45, 83-94]. They have an enzymatic antioxidant mechanism to control oxidative stress caused by heavy metals and reduce damage [83]. Duckweeds relieve the stress of heavy metals that affect nutrient absorption by activating antioxidative mechanisms [85]. The chelating action of duckweeds can also alleviate the stress caused by heavy metals, such as chromium (IV) $[85,93]$.

The release of diverse pharmaceuticals into environment severely affects various plants and animals, and their removal through phytoremediation is important. L. turionifera and W. borealis could remove pharmaceuticals, such as acetaminophen, fluoxetine, progesterone, and sulfamethoxazole [71]. L. minor can remove benzotriazoles used in anti-corrosion products, coolants, and dishwashing liquids [95]. L. turionifera can eliminate pesticides, such as imidacloprid insecticide, from contaminated water [96]. L. gibba was used for the remediation of fresh water contaminated with nonsteroidal anti-inflammatory drug ibuprofen [97]. Applications of L. gibba for removing tetracycline and $L$. minor for removal antimicrobials have also been reported [98, 99].

Industrial wastewater from modern factories and sewage from large animal farms, hospitals, and homes are known to cause problems in aquatic environments. Duckweeds could be the best aquatic purification plant. Phytoremediation using duckweeds is a cost-effective and environmentally friendly strategy to prevent environmental pollution and preserve aquatic and terrestrial ecosystems. However, the purification capacity of duckweeds and disposal of contaminated duckweeds should be thoroughly considered. 
Table 3 List of duckweeds used as phytoremediation resources

\begin{tabular}{|c|c|c|}
\hline Phytoremediation targets & Species & References \\
\hline \multicolumn{3}{|l|}{ Inorganic } \\
\hline Ammonium & Landoltia punctata & {$[19]$} \\
\hline Arsenic & L. gibba, L. valdiviana, S. intermedia, and W. arrhiza & {$[83,87-89]$} \\
\hline Boron & L. gibba & {$[11,74]$} \\
\hline Cadmium & L. minor and L. trisulca & [90-92] \\
\hline Chromium & S. polyrrhiza & {$[93]$} \\
\hline Cobalt & Landoltia punctata & [94] \\
\hline Copper & L. aequinoctialis, L. gibba, L. minor, and L. trisulca & {$[84,85,91,92]$} \\
\hline Fluoride & S. polyrrhiza & {$[78]$} \\
\hline Iron & L.minor & {$[77]$} \\
\hline Lead & L. perpusilla & {$[86]$} \\
\hline Nickel & Landoltia punctata and L. minor & {$[90,94]$} \\
\hline Nitrogen & Landoltia punctata, L. gibba, L. minuta, and S. polyrrhiza & {$[19,70,76,79-81]$} \\
\hline Phosphorous & $\begin{array}{l}\text { Landoltia punctata, L. gibba, L. minuta, L. turionifera, S. polyrrhiza, } \\
\text { and W. borealis }\end{array}$ & {$[70,71,76,79-81]$} \\
\hline Selenium & L. minuta & {$[45]$} \\
\hline Sulfate & L.gibba & {$[76]$} \\
\hline Zinc & L. minor and L. minuta & {$[45,90]$} \\
\hline \multicolumn{3}{|l|}{ Organic } \\
\hline Dairy industry processing wastewater & L.minor & {$[100]$} \\
\hline Hydrocarbons in crude oil-contaminated wetlands & L. aequinoctialis & {$[101]$} \\
\hline Synthetic dyes & L.minor & {$[102]$} \\
\hline Wastewater & Landoltia punctate and W. arrhiza & {$[7,17]$} \\
\hline \multicolumn{3}{|l|}{ Pharmaceutical } \\
\hline Acetaminophen & L. turionifera and $W$. borealis & {$[71]$} \\
\hline Antimicrobials & L.minor & {$[99]$} \\
\hline Benzotriazoles & L.minor & {$[95]$} \\
\hline Fluoxetine & L. turionifera and W. borealis & {$[71]$} \\
\hline Ibuprofen & L.gibba & {$[97]$} \\
\hline Imidacloprid & L. turionifera & {$[96]$} \\
\hline Progesterone & L. turionifera and W. borealis & {$[71]$} \\
\hline Sulfamethoxazole & L. turionifera and W. borealis & {$[71]$} \\
\hline Tetracycline antibiotics & L.gibba & [98] \\
\hline
\end{tabular}

L. Lemna, S. Spirodela, W. Wolffia

\section{Biofuels, space exploration, and bioplastics}

In recent years, interest in the developing alternative energy sources has increased owing to environmental problems and climate changes. Biofuels are renewable energy alternatives to fossil fuels and include bioalcohols, biodiesel, and biogas. Duckweeds have been used for bioethanol production as a renewable energy resource [25]. With the increasing need for biomass, research has focused on duckweeds and their starch content. Under proper conditions, the doubling time of duckweed biomass ranges from 1.34 to 4.54 days [4]. Starch could be used for bioethanol production through a considerably simple conversion process [25]. Duckweed biomass production is economical because, unlike corn, duckweeds do not require mechanical grinding; additionally, the byproduct of ethanol fermentation has a high protein content that could be reused as livestock feed [25].

As listed in Table 4, duckweeds have been used as a resource for biomass and biofuel production. Duckweeds with a high starch content, high biomass production, and low lignin content could be promising sources of bioethanol production [103]. Duckweeds can be enzymatically converted to bioethanol by fermentation without thermophysical pretreatment [104]. L. aequinoctialis and S. polyrrhiza have been selected to increase bioethanol yield as they have a high starch content and biomass production capacity $[105,106]$. S. polyrrhiza could be utilized as a substitute for corn starch to make the bioethanol industry 
Table 4 List of duckweeds used in biofuels and bioplastics applications

\begin{tabular}{|c|c|c|}
\hline Usages & Species & References \\
\hline Biobutanol & Landoltia punctata & [103] \\
\hline Biodegradable plastics for various industrial products & Lemna sp. & [115] \\
\hline Bioethanol & L. aequinoctialis, L. minor, and S. polyrrhiza & {$[104-106]$} \\
\hline Biofuels & L. gibba, S. polyrrhiza, and W. australiana & [109] \\
\hline Biogas & L.minor & [108] \\
\hline Biomass production as a bioregenerative system for space exploration & L. aequinoctialis, L. gibba, and W. globosa & {$[111,112]$} \\
\hline Photosynthetic producer in space exploration & W. arrhiza & [113] \\
\hline Plant fuel cell & L. minuta & {$[110]$} \\
\hline
\end{tabular}

L. Lemna, S. Spirodela, W. Wolffia

sustainable because its ethanol yield $\left(6.42 \times 10^{3} 1 \mathrm{ha}^{-1}\right)$ has been found to be higher than that of corn $\left(4.31 \times 10^{3} \mathrm{lha}^{-1}\right)$ [106]. Cytokinin treatment has been suggested as a good option to increase the growth rate of and starch accumulation in S. polyrrhiza [107].

Landoltia punctata could be used for biobutanol production by a mutant strain of yeast [103]. L. minor can be pyrolyzed to produce biochar, and biochars are catalysts for biogas [108]. After extracting starch from duckweeds, the residual cell wall can be broken down into sugars and uronic acids, which can be converted into biofuel sources [109]. Additionally, L. minuta has been reported as an ecofriendly energy resource that converts solar energy into electricity by acting as a plant fuel cell to generate electricity [110].

L. aequinoctialis and $W$. globosa have a high relative growth rate even under microgravity, making them suitable for use in space exploration [111]. L. gibba is also suitable for agriculture and bioregeneration systems for space exploration because it has shown a high growth rate under an extreme range of lighting from low growth luminosity to a total daily photon mass similar to that received on the brightest and longest days [112]. In long-term space exploration, $W$. arrhiza could also be a photosynthetic producer [113].

Duckweeds can be utilized as resources for biodegradable plastics. Biodegradable plastics are polymers that can be degraded by living organisms and are invented as alternatives to non-degradable plastics [114]. Lemna species produce biodegradable plastics for various industrial products [115]. Blending duckweed biomass and polyethylene has shown good stability and matrix characteristics [115].

\section{Useful metabolites in duckweeds}

\section{Proteins, carbohydrates, and fats in duckweeds}

Table 5 lists the total content of proteins, carbohydrates, and fats in various duckweeds. The proportion of the total content of amino acids in duckweeds was the highest compared with that of carbohydrates and fatty acids.
The total protein content of duckweeds ranges from $19.8 \%$ to $48.2 \%$ per dry weight. Relatively higher level of total amino acid (48.2\%) per dry weight was observed in W. globosa [116]. Relatively higher level of total carbohydrate content (38\%) was reported in L. gibba [117]. In addition, total fatty acid content was relatively higher in L. minor (11.4\%) [30].

The nine essential amino acids found in the duckweed species are histidine, isoleucine, leucine, lysine, methionine, phenylalanine, threonine, tryptophan, and valine and eleven non-essential amino acids, namely alanine, arginine, asparagine, aspartate, cysteine, glutamate, glutamine, glycine, proline, serine, and tyrosine, were also found in duckweeds (Table 6) $[9,15,54,116,122]$. Amino acid derivatives, such as citrulline, cystathionine, hydroxyproline, $\gamma$-aminobutyric acid (GABA), and taurine, were also found (Table 6) [54, 122]. Notably, the amino acid compositions of W. microscopica and Wolffiella hyalina are close to the content of lysine $(30 \mathrm{mg} /$ $\mathrm{kg})$, sulfur amino acids $(15 \mathrm{mg} / \mathrm{kg})$ including cysteine and methionine, threonine $(15 \mathrm{mg} / \mathrm{kg})$, and tryptophan $(4 \mathrm{mg} / \mathrm{kg})$ required for adults per day according to WHO recommendations. Additionally, the contents of cysteine and methionine are $22 \%$ higher than the recommended allowance [43].

Carbohydrates in duckweeds comprised sugars, polysaccharides, and starch. Sugars, such as apiose, arabinose, fructose, fucose, galactose, glucose, mannose, raffinose, rhamnose, sucrose, and xylose, were found in duckweeds (Table 6) $[10,75]$. The compositions of duckweed cell walls were similar among species, consisting of pectin and hemicellulose [109]. Among the polysaccharides that do not make up the cell wall, inulin has been reported [120]. Starch accounts for approximately $4.0 \%$ to $29.8 \%$ of duckweed species, as listed in Table 5. High levels of starch accumulation have been observed under nutritional deficiency conditions in $S$. polyrrhiza [106]. Adequate salinity condition $(150 \mathrm{mM}$ $\mathrm{NaCl}$ ) induce starch accumulation in Landoltia 
Table 5 Total contents of proteins, carbohydrates, and fats in duckweeds

\begin{tabular}{|c|c|c|c|c|}
\hline Duckweed species & Proteins & Carbohydrates & Fats & References \\
\hline \multicolumn{5}{|l|}{ Landoltia } \\
\hline Landoltia punctata & $20-28.7 \%$ & $10-11.20 \%$ (Starch) & $4-5.5 \%$ & {$[9,118,119]$} \\
\hline \multicolumn{5}{|l|}{ Lemna } \\
\hline L. aequinoctialis & $34.18 \%$ & $11.61-28.68 \%$ (Starch) & NS & {$[69,105,119]$} \\
\hline L.gibba & $21.5-37.9 \%$ & $17.6-38.0 \%$ & $4.4-9.3 \%$ & {$[117,118,120]$} \\
\hline L.minor & $20-38.30 \%$ & $4 \%$ (Starch) & $11.4 \%$ & {$[9,30,42]$} \\
\hline \multicolumn{5}{|l|}{ Spirodela } \\
\hline S. polyrrhiza & $25.6-34.5 \%$ & $11.14-29.8 \%$ (Starch) & $4.5 \%$ & {$[46,105,106,118,119,121]$} \\
\hline \multicolumn{5}{|l|}{ Wolffia } \\
\hline W. arrhiza & $19.8-20.15 \%$ & $43.6 \%$ & $2.43-5.0 \%$ & {$[36,116]$} \\
\hline W. columbiana & $36.5-44.7 \%$ & NS & $6.6 \%$ & {$[116,118]$} \\
\hline W. globosa & $33.3-48.2 \%$ & $11.05 \%$ (Starch) & $5.0-9.6 \%$ & {$[116,119]$} \\
\hline \multicolumn{5}{|l|}{ Wolffiella } \\
\hline Wolffiella hyalina & $35 \%$ & NS & $7 \%$ & {$[9]$} \\
\hline
\end{tabular}

L. Lemna, S. Spirodela, W. Wolffia, NS not specified

The value before (starch) represents the starch content

Table 6 List of amino acids, saccharides, and fatty acids in duckweeds

\begin{tabular}{|c|c|c|}
\hline \multicolumn{2}{|l|}{ Compounds } & \multirow[t]{2}{*}{ References } \\
\hline Proteins & & \\
\hline Amino acids & $\begin{array}{l}\text { Alanine, arginine, asparagine, aspartate, cysteine, glutamate, glutamine, glycine, histidine, } \\
\text { isoleucine, leucine, lysine, methionine, phenylalanine, proline, serine, threonine, tryptophan, } \\
\text { tyrosine, and valine }\end{array}$ & {$[9,15,54,116,122]$} \\
\hline Amino acid derivatives & Citrulline, cystathionine, hydroxyproline, $\gamma$-aminobutyric acid (GABA), and taurine & {$[54,122]$} \\
\hline \multicolumn{3}{|l|}{ Carbohydrates } \\
\hline Sugars & $\begin{array}{l}\text { Apiose, arabinose, fructose, fucose, galactose, glucose, mannose, raffinose, rhamnose, } \\
\text { sucrose, and xylose }\end{array}$ & {$[10,75]$} \\
\hline Polysaccharides & Inulin, pectin, and hemicellulose & {$[109,120]$} \\
\hline Starch & Starch & {$[9,75,119]$} \\
\hline \multicolumn{3}{|l|}{ Fats } \\
\hline Long-chain fatty acids & $\begin{array}{l}\text { Behenic acid, eicosanoic acid, 6-hexadecenoic acid, 2-hydroxypalmitic acid, lignoceric acid, } \\
\text { a-linolenic acid, } y \text {-linolenic acid, linoleic acid, linolenic acid, myristic acid, nonadecylic acid, } \\
\text { oleic acid, palmitelaidic acid, palmitic acid, pentadecylic acid, stearic acid, and stearidonic } \\
\text { acid }\end{array}$ & {$[9,17,32,119,120,123,124]$} \\
\hline Medium-chain fatty acids & Lauric acid & {$[120,123]$} \\
\hline Short-chain fatty acids & $C 2, C 3, C 4$, and $C 5$ & {$[28]$} \\
\hline
\end{tabular}

punctata, $L$. aequinoctialis, $L$. gibba, L. minor, and $S$. intermedia [125]. However, duckweeds produce low total protein levels under saline condition $(10,20$, and $30 \mathrm{mmol} / \mathrm{L} \mathrm{NaCl}$ concentration) [106]. Therefore, when choosing salt treatment as an induction method to increase biomass for biofuel production, circumspection regarding its correlation with protein levels is required. L. aequinoctialis and S. polyrrhiza are known as high-starch duckweed species; therefore, they can be utilized in the biofuel industry $[105,106]$.
As listed in Table 5, the total fatty acids content ranges from $1.05 \%$ to $1.62 \%$ and the triacylglycerol composition is $0.02 \%$ in Landoltia punctata, L. aequinoctialis, $S$. polyrrhiza, and W. globosa [119]. The fatty acids found in duckweeds included behenic acid, eicosanoic acid, 6-hexadecenoic acid, 2-hydroxypalmitic acid, lauric acid, lignoceric acid, $\alpha$-linolenic acid, $\gamma$-linolenic acid, linoleic acid, linolenic acid, myristic acid, nonadecylic acid, oleic acid, palmitelaidic acid, palmitic acid, pentadecylic acid, stearic acid, and stearidonic acid (Table 6) $[9,17,32$, 
$119,120,123]$. Three fatty acids-linoleic acid, linolenic acid, and palmitic acid-are dominant, accounting for approximately $80 \%$ of the total fatty acids [119]. The content of $\alpha$-linolenic acid is also particularly high (between 11 and 25\%) [9]. The ratio of omega-3 to omega- 6 fatty acids in duckweeds has been reported to range from $5: 3$ to 4:1 [9]. Increased consumption of omega-3 fatty acids could prevent inflammatory diseases, cancer, cardiovascular diseases, and other chronic diseases, therefore, the omega-3:omega- 6 ratio in duckweeds is noteworthy [126].

Short chain fatty acids (SCFAs) have also been identified in L. minor, the total SCFA is $16.6 \mathrm{mM}$, of which $\mathrm{C}_{2}$ and $C_{3}$ account for 11.8 and $3.1 \mathrm{mM}$, respectively [28]. SCFAs can be absorbed into colon epithelial cells through diffusion or active transport; $\mathrm{C}_{2}$ and $\mathrm{C}_{3}$, in particular, are easily transported to other cells and organs [127]. SCFAs have been reported to contribute to the healthy intestinal environment, regulate the immune system, and prevent colorectal cancer [127, 128]. Despite their substantial potential as bioactive materials, profiling individual intact lipid species in duckweeds has rarely been performed. Further investigation should be conducted to reveal the profiles of such lipid species in various duckweed species to broaden application of duckweeds.

\section{Secondary metabolites in duckweeds}

As listed in Table 7, duckweeds contain various useful secondary metabolites including phenolic compounds (flavonoids, phenylpropanoids, and tannins) and terpenoids. Various physiological properties have facilitated their utility, and they have been highlighted in the pharmaceutical, cosmetics, and food industries.

Phenolic compounds are bioactive compounds with diverse pharmacological activities in humans [129]. The total phenolic content ranges from $1.3 \%$ to $2.9 \%$ in $L$. minor [30]. As listed in Table 7, the phenolic compounds detected in duckweeds are flavonoids, hydroxycinnamic acids, and tannin. The flavonoids in duckweeds are apigenin, luteolin, and their derivatives (Table 7). Duckweeds are known to have a higher flavonoid content (>2\%) than most other plants (0.5\% to $1.5 \%)$ [94]. In particular, S. polyrrhiza and W. globosa has a high flavonoid content (4.22\% and $5.85 \%$, respectively), which could be advantageous in producing flavonoids [130]. Landoltia punctata showed significant apigenin content, and the contents of luteolin and its derivatives were high in $L$. gibba, S. polyrrhiza, W. borealis, and Wolffiella caudata [59]. Landoltia punctata, S. polyrrhiza, W. borealis, and Wolffiella caudata contain abundant $C$-glycosylated flavonoids, which exhibit high antioxidant activity $[59,131]$. Apigenin and vitexin of Landoltia punctata could be used as anticancer adjuvants, and flavone $C$ - glycosides from L. japonica exhibits cytotoxic activity against various human cancer cell lines, such as HepG-2, SW-620, and A-549 [59, 132]. Anthocyanins have been detected in L. gibba and S. intermedia and exhibit antioxidant properties [83, 87]. Hydroxycinnamic acids detected in duckweeds include caffeic acid, cinnamic acid, m-coumaric acid, p-coumaric acid, ferulic acid, isofelulic acid, and sinapic acid [17, 123, 133, 134]. Hydroxycinnamic acids possess antibacterial, anticollagenase, anti-inflammatory, anti-obesity, antioxidant, anti-tyrosinase, neuroprotection, and ultraviolet protection activities that could contribute to human health $[135,136]$.

Terpenoids (isoprenoids) have been widely utilized in the pharmaceutical, food, cosmetic, pesticide, chemical industries [137]. Terpenoids such as carotenoids, phytosterols, and saponins, have been detected in duckweeds (Table 7). Neophytadiene, 24-methylenecycloartan3-one, saponin, and squalene have also been reported [17, 28, 42, 58, 134]. Saponins, including 24-dehydroechinoside, echinoside $\mathrm{A}$, stichoposide $\mathrm{C}$, and stichoposide D, show antitumor, hypolipidemic activity, and antihypertensive effects and suppress fat accumulation [138]. L. minor contains a total saponin content $3.2 \mathrm{~g} / \mathrm{kg}$ dried weight [28]. Phytosterols, such as $\Delta 5$-avenasterol, campesterol, cycloartenol, $\beta, \delta$-sitosterol, and stigmasterol, have been reported in duckweeds [9, 17, 124, 133, 134]. Phytosterols account for approximately $20 \%$ of the wax fraction of S. polyrrhiza [134]. Phytosterols are cholesterol-lowering agents that reduce serum and liver cholesterol [139]. Carotenoids belonging to the tetraterpene found in duckweeds included $\alpha$-carotene, $\beta$-carotene, loliolide, lutein, lycopene, violaxanthin, xanthophyll, and zeaxanthin $[9,30,112,120,124]$.

\section{Cultivation}

Duckweed species are distributed in various regions in the natural environment, except for deserts and polar regions [6]. The growth of duckweed species is exponential and faster than most other plants under appropriate carbon dioxide, light, $\mathrm{pH}$, temperature, and nutrient supply conditions [15, 73]. Table 8 lists the culture conditions of various duckweeds. Erlenmeyer flasks, Magenta vessel, and Petri dishes have been used for most small-volume cultures $(<500 \mathrm{~mL})[4,75,96,100,104,107,140-142$, 161]. Small-scale cultures should be subcultured periodically, and the light-dark cycle and temperature conditions should be constant to achieve a uniform growth rate and constant nutrient contents.

It is important which culture medium to choose because incorrect selection can lead to physiological disturbances or death of the plants [143]. Schenk and Hildebrandt medium, Hutner medium, Murashige and Skoog medium, and Hoagland medium are generally used as 
Table 7 Secondary metabolites in duckweeds

\begin{tabular}{|c|c|c|c|c|}
\hline & & Contents & Species & References \\
\hline \multirow[t]{29}{*}{ Phenolic compounds } & \multirow[t]{21}{*}{ Flavonoids } & Anthocyanin & L. gibba and S. intermedia & {$[83,87]$} \\
\hline & & Apigenin & Landoltia punctata and S. polyrrhiza & {$[59,131]$} \\
\hline & & $\begin{array}{l}\text { Apigenin 6-C-(2"-O-trans-caffeoyl-D- } \\
\text { malate)- } \beta \text {-glucoside }\end{array}$ & L.japonica & [132] \\
\hline & & Apigenin 7-O-glucoside & S. polyrrhiza & {$[59,131]$} \\
\hline & & Apigenin 8-C-glucoside (vitexin) & $\begin{array}{l}\text { Landoltia punctata, L. gibba, and S. } \\
\text { polyrrhiza }\end{array}$ & {$[59,131]$} \\
\hline & & 5-O-(E)-caffeoylquinic acid & Landoltia punctata and S. polyrrhiza & [59] \\
\hline & & 3-O-(E)-coumaroylquinic acid & S. polyrrhiza & [59] \\
\hline & & 6,8-Di-C- $\beta$-glucosylapigenin & L.japonica & {$[132]$} \\
\hline & & 6,8-Di-C- $\beta$-glucosylluteolin & L.japonica & [132] \\
\hline & & Isoorientin & L.japonica & [132] \\
\hline & & Isovitexin & L.japonica & [132] \\
\hline & & Luteolin & S. polyrrhiza & [131] \\
\hline & & $\begin{array}{l}\text { Luteolin-6-C-glucoside-8-C-rhamno- } \\
\text { side }\end{array}$ & Landoltia punctata and W. borealis & [59] \\
\hline & & $\begin{array}{l}\text { Luteolin 6-C-(2"-O-trans-caffeoyl-D- } \\
\text { malate)- } \beta \text {-glucoside }\end{array}$ & L.japonica & [132] \\
\hline & & $\begin{array}{l}\text { Luteolin 6-C-(2"-O-trans-coumaroyl-D- } \\
\text { malate)- } \beta \text {-glucoside }\end{array}$ & L.japonica & [132] \\
\hline & & Luteolin 7-O-glucoside & S. polyrrhiza & {$[59,131]$} \\
\hline & & Luteolin-7-O- $\beta$-glucoside & L.japonica & {$[132]$} \\
\hline & & Luteolin-7-O-glucoside-C-glucoside & $\begin{array}{l}\text { Landoltia punctata, W. borealis, and } \\
\text { Wolffiella caudata }\end{array}$ & {$[59]$} \\
\hline & & Luteolin 8-C-glucoside (orientin) & S. polyrrhiza and $W$. borealis & {$[59,131]$} \\
\hline & & $\begin{array}{l}\text { Luteolin-8-C-glucoside-6-C-rhamno- } \\
\text { side }\end{array}$ & $\begin{array}{l}\text { Landoltia punctata, L. gibba, W. borealis, } \\
\text { and Wolffiella caudata }\end{array}$ & [59] \\
\hline & & Luteolin-8-C-glucoside-6-C-xyloside & $\begin{array}{l}\text { Landoltia punctata, L. gibba, and W. } \\
\text { borealis }\end{array}$ & [59] \\
\hline & \multirow[t]{7}{*}{ Hydroxycinnamic acids } & Caffeic acid & L. aequinoctialis and W. arrhiza & {$[17,133]$} \\
\hline & & Cinnamic acid & S. polyrrhiza & [134] \\
\hline & & m-Coumaric acid & L. aequinoctialis & [133] \\
\hline & & p-Coumaric acid & L. aequinoctialis, L. minor, and W. arrhiza & {$[17,123,133]$} \\
\hline & & Ferulic acid & L. minor and W. arrhiza & {$[17,123]$} \\
\hline & & Isoferulic acid & L. aequinoctialis & [133] \\
\hline & & Sinapic acid & L. aequinoctialis & [133] \\
\hline & Tannin & Tannin & $\begin{array}{l}\text { L. aequinoctialis, L. minor, and S. polyr- } \\
\text { rhiza }\end{array}$ & {$[28,58,69]$} \\
\hline \multirow[t]{11}{*}{ Terpenoids } & Diterpenoid & Neophytadiene & W. arrhiza & {$[17]$} \\
\hline & \multirow[t]{9}{*}{ Triterpenoids } & $\Delta 5$-Avenasterol & W. microscopica & {$[9]$} \\
\hline & & Campesterol & $\begin{array}{l}\text { L. aequinoctialis, L. minor, S. polyrrhiza, } \\
\text { W. arrhiza, and W. microscopica }\end{array}$ & {$[9,17,124,133,134]$} \\
\hline & & Cycloartenol & W. microscopica & [9] \\
\hline & & 24-Methylenecycloartan-3-one & W. arrhiza & {$[17]$} \\
\hline & & Saponin & L. minor and S. polyrrhiza & {$[28,42,58]$} \\
\hline & & $\beta$-Sitosterol & $\begin{array}{l}\text { L. aequinoctialis, S. polyrrhiza, W. arrhiza, } \\
\text { and W. microscopica }\end{array}$ & {$[9,17,133,134]$} \\
\hline & & $\delta$-Sitosterol & L.minor & [124] \\
\hline & & Stigmasterol & $\begin{array}{l}\text { L. aequinoctialis, L. minor, S. polyrrhiza, } \\
\text { W. arrhiza, and W. microscopica }\end{array}$ & {$[9,124,133,134]$} \\
\hline & & Squalene & S. polyrrhiza & [134] \\
\hline & Tetraterpenoids & a-Carotene & L.gibba & [120] \\
\hline
\end{tabular}


Table 7 (continued)

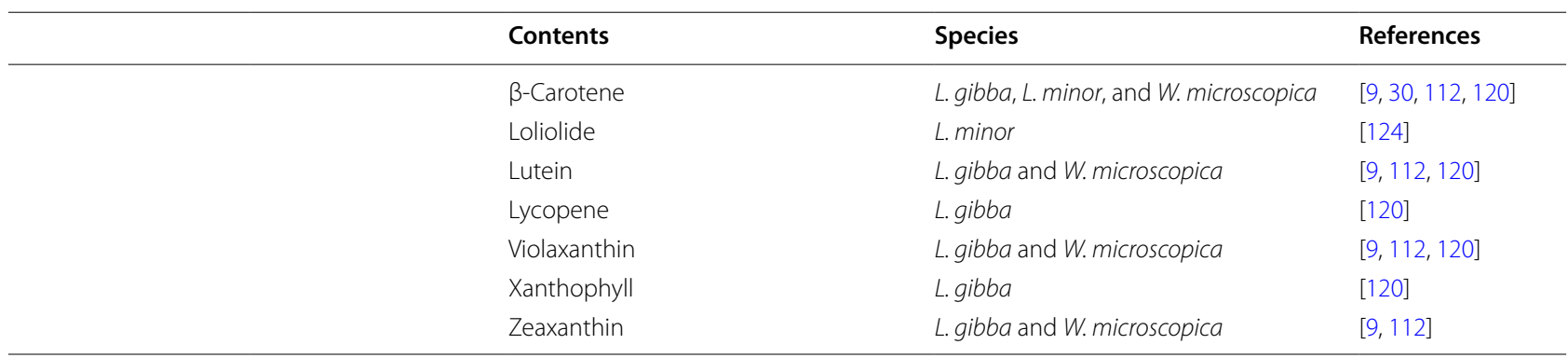

L. Lemna, S. Spirodela, W. Wolffia

refined media for the culture of various duckweeds. Schenk and Hildebrandt medium contains sucrose as the carbon source and $\mathrm{KNO}_{3}$ as a nitrogen source [144]. Regarding nitrogen sources, Hutner medium contains $\mathrm{NH}_{4} \mathrm{NO}_{3}$, Murashige and Skoog medium contains $\mathrm{NH}_{4} \mathrm{NO}_{3}$ and $\mathrm{KNO}_{3}$, and Hoagland medium contains $\mathrm{Ca}\left(\mathrm{NO}_{3}\right)_{2}$ and $\mathrm{KNO}_{3}$ [145-147]. The differences in nitrogen sources could affect the starch and biomass production of duckweeds $[105,148]$.

In mass production $(>500 \mathrm{~mL})$, duckweeds are cultivated in artificial environments (bioreactors) or natural ponds, well water, dairy, and local wastewater [11, 37, $54,73,83,105,106,112,149,150,162]$. Under optimal environment conditions, including wind protection, water nutrient concentration, and optimum duckweed density, duckweeds can produce biomass with a productivity of 10-30 tons/ha per year $[6,151]$. In open pond systems, $S$. polyrrhiza in organic manure and inorganic fertilizer is high in protein and carbohydrate contents, respectively [54]. Duckweeds grow rapidly even in animal wastewater, producing high biomass [106]. In the natural underground water, duckweeds have a tendency to grow slowly, lengthen roots, and possess lower protein content because of insufficient nitrogen and mineral nutrients $[6,106]$. Conditions of essential phytonutrients, such as ammonium, calcium, magnesium, nitrogen, and phosphorous, affect the biomass of duckweeds [73].

Duckweeds grow in a wide $\mathrm{pH}$ range of 3.5 to 9.0 , and the optimal $\mathrm{pH}$ range is between 6.5 and $7.5[6,73,152$, 153]. The $\mathrm{pH}$ determines the ratio of $\mathrm{NH}_{3}$ to $\mathrm{NH}_{4}{ }^{+}$in the culture medium. As the $\mathrm{pH}$ increases, $\mathrm{NH}_{4}{ }^{+}$increases, thus preventing the transport of anions in the duckweed membrane and eventually reducing growth, high $\mathrm{NH}_{3}$ at low $\mathrm{pH}$ exhibits toxicity $[73,153]$. The $\mathrm{pH}$ also has a significant effect on the conversion of duckweed biomass into biobutanol. Bacterial growth yields sufficient butanol for industrial use when culture maintained between $\mathrm{pH}$ 4.5 and 5.0 [103].

Light intensity and duckweed growth rate show a direct relationship, unless the light intensity is too high. The lowest growth rate was at a low intensity of $6 \mu \mathrm{mol} \mathrm{m} \mathrm{m}^{-2} \mathrm{~s}^{-1}$, and the growth rate increased with increasing light intensity to $1000 \mu \mathrm{mol} \mathrm{m} \mathrm{m}^{-2} \mathrm{~s}^{-1}$ [141]. Duckweeds accumulate antioxidants to prevent damage when exposed to excessive light. However, it has been proposed that the choice of optimal light intensity balances light efficiency with the antioxidant contents [112]. It was also reported that different light qualities affected the growth and physiological characteristics of duckweeds. Irradiation with ultra-high-frequency electromagnetic radiation has increased the growth rate and biomass, whereas infrared irradiation increased the number of fronds in L. minor culture [154]. However, ultraviolet rays delay the development of duckweeds and the growth of the root system, and radiofrequency radiation induced oxidative stress in the plants $[154,155]$.

In a natural environment, duckweeds generally grow in the range of 6 to $33{ }^{\circ} \mathrm{C}$; the optimum water temperature for duckweeds growth is between 19 and $30{ }^{\circ} \mathrm{C}[6,73$, 152]. In late summer in the temperate climate region of the world, duckweeds undergo a morphological change called turion because of the reduction in temperatures [6]. They sink into water bodies, storing starch as energy for the next growing season, and remain dormant. When the temperature increases in spring, they germinate because of light $[156,157]$. Turion-type duckweeds could be suggested as useful biofuel feedstock because of their high anthocyanin and starch contents and low lignin content $[156,157]$. Under controlled laboratory conditions, induction of conversion to turion by abscisic acid treatment has been possible for S. polyrrhiza [156].

According to diverse goals and targets, optimal cultivation of duckweeds will be necessary from an economic and industrial point of view. Various culture methods of duckweeds using diverse types of bioreactors and conditions should be employed for the utilization as food, pharmaceutical, phytoremediation, and biofuel resources. Aquaponics that combine aquaculture and hydroponics could be a sustainable production system for plants [158]. Additionally, the cultivation of various plants employing 
Table 8 Culture conditions of duckweeds

\begin{tabular}{|c|c|c|c|c|c|}
\hline Culture volume & Culture scale & Culture medium & Species & $\begin{array}{l}\mathrm{pH} / \text { light/temperature/culture } \\
\text { period }\end{array}$ & Refs. \\
\hline \multicolumn{6}{|l|}{$\leq 50 \mathrm{~mL}$} \\
\hline $10 \mathrm{~mL}$ & Magenta vessel & $1 / 2 \mathrm{SH}$ & L.turionifera & $\mathrm{pH} 6.0 / 23^{\circ} \mathrm{C}$ in light $/ 21^{\circ} \mathrm{C}$ in the dark & {$[96]$} \\
\hline $10 \mathrm{~mL}$ & Petri dish $(60 \times 10 \mathrm{~mm})$ & $1 / 2 \mathrm{SH}$ & L. turionifera & $\begin{array}{l}23.8-29.7^{\circ} \mathrm{C} \text { in light } / 21.5^{\circ} \mathrm{C} \text { in } \\
\text { dark/4 days }\end{array}$ & {$[140]$} \\
\hline $50 \mathrm{~mL}$ & Petri dish & $1 / 2$ Hutner & L. minor and L. minuta & $\begin{array}{l}6,10,20,30,40,90,150,250,400, \text { or } \\
1000 \mu \mathrm{mol} \mathrm{m}-2 \mathrm{~s}^{-1} / 20^{\circ} \mathrm{C}\end{array}$ & {$[141$} \\
\hline \multicolumn{6}{|l|}{$50-100 \mathrm{~mL}$} \\
\hline $100 \mathrm{~mL}$ & Petri dish $(100 \times 15$ mm) & Hoagland & $\begin{array}{l}\text { Lemna sp., Spirodela sp., } \\
\text { Wolffia sp., Wolfiella sp. }\end{array}$ & $\begin{array}{l}\mathrm{pH} 5.8 / 40 \mu \mathrm{mol} \mathrm{m}{ }^{-2} \mathrm{~s}^{-1} / 23^{\circ} \mathrm{C} / \\
2 \text { weeks }\end{array}$ & {$[161]$} \\
\hline $100 \mathrm{~mL}$ & & $1 / 2 \mathrm{SH}$ & $\begin{array}{l}\text { Landoltia spp., Lemna spp., } \\
\text { Spirodela spp., Wolffia spp., } \\
\text { and Wolffiella spp. }\end{array}$ & $\begin{array}{l}\mathrm{pH} 6.5 / 20 \text { or } \\
500 \mu \mathrm{mol} \mathrm{m}{ }^{-2} \mathrm{~s}^{-1} / 25^{\circ} \mathrm{C} / 1 \text { week }\end{array}$ & {$[75]$} \\
\hline $100 \mathrm{~mL}$ & Erlenmeyer flask (250 ml) & Hoagland & L.minor & $\mathrm{pH} 5.8 / 120 \mu \mathrm{mol} \mathrm{m}{ }^{-2} \mathrm{~s}^{-1} / 22^{\circ} \mathrm{C}$ & {$[104]$} \\
\hline $100 \mathrm{~mL}$ & Erlenmeyer flask (500 ml) & $\mathrm{SH}$ & L. gibba and S. polyrrhiza & $80 \mu \mathrm{mol} \mathrm{m}{ }^{-2} \mathrm{~s}^{-1} / 24^{\circ} \mathrm{C}$ & {$[107]$} \\
\hline $100 \mathrm{~mL}$ & $\begin{array}{l}\text { Magenta vessel } \\
(77 \times 77 \times 97 \mathrm{~mm})\end{array}$ & $\begin{array}{l}\text { Synthetic dairy wastewa- } \\
\text { ter or } \\
1 / 2 \text { Hutner }\end{array}$ & L.minor & $\begin{array}{l}\mathrm{pH} 4.5-5 / 80.82 \mu \mathrm{mol} \mathrm{m}{ }^{-2} \mathrm{~s}^{-1} / 21^{\circ} \mathrm{C} \\
/ 1 \text { week }\end{array}$ & {$[100]$} \\
\hline \multicolumn{6}{|l|}{$100-500 \mathrm{~mL}$} \\
\hline $180 \mathrm{~mL}$ & Erlenmeyer flask (300 mL) & Modified SH & $\begin{array}{l}\text { Landoltia spp., Lemna spp., } \\
\text { Spirodela spp., Wolffia spp., } \\
\text { and Wolffiella spp. }\end{array}$ & $\begin{array}{l}\mathrm{pH} 5.5 / 100 \mu \mathrm{mol} \mathrm{m}{ }^{-2} \mathrm{~s}^{-1} / 25 \pm 1^{\circ} \mathrm{C} / \\
1 \text { week }\end{array}$ & {$[4]$} \\
\hline $250 \mathrm{~mL}$ & Flask (500 mL) & Hoagland & L.minor & $\mathrm{pH} 7.0 / 75 \mu \mathrm{mol} \mathrm{m}{ }^{-2} \mathrm{~s}^{-1} / 28^{\circ} \mathrm{C} / 10$ days & {$[142]$} \\
\hline \multicolumn{6}{|l|}{$500-1000 \mathrm{~mL}$} \\
\hline \multirow[t]{2}{*}{$600 \mathrm{~mL}$} & Glass beaker $(2 \mathrm{~L})$ & $1 / 2 \mathrm{MS}$ & S. polyrrhiza & $\mathrm{pH} 5.8 / 5000 \mathrm{I} \times / 25 \pm 1{ }^{\circ} \mathrm{C}$ & [149] \\
\hline & $\begin{array}{l}\text { Plastic box }(750 \mathrm{~mL}) \\
(12.5 \times 12.5 \times 4.2 \mathrm{~cm})\end{array}$ & SH or tap water & $\begin{array}{l}\text { L. aequinoctialis and S. } \\
\text { polyrrhiza }\end{array}$ & $\begin{array}{l}\mathrm{pH} 5.8 / 110 \mu \mathrm{mol} \mathrm{m} \mathrm{m}^{-2} \mathrm{~s}^{-1} / 25^{\circ} \mathrm{C} / 1 \\
\text { week }\end{array}$ & {$[105]$} \\
\hline $1000 \mathrm{~mL}$ & $\begin{array}{l}\text { Crystallizing dish } \\
(1200 \mathrm{~mL})(150 \times 75 \mathrm{~mm})\end{array}$ & $\mathrm{SH}$ & L.gibba & $\begin{array}{l}\mathrm{pH} 5.5 / 100,200,500, \text { or } \\
700 \mu \mathrm{mol} \mathrm{m} \mathrm{m}^{-2} \mathrm{~s}^{-1} / 25^{\circ} \mathrm{C} / 4 \text { days }\end{array}$ & {$[112]$} \\
\hline \multicolumn{6}{|l|}{$1 \mathrm{~L}<$} \\
\hline $2.3 \mathrm{~L}$ & Glass vessel $(2.5 \mathrm{~L})$ & $\begin{array}{l}\text { Influent wastewater or } \\
1 / 50 \text { Hutner }\end{array}$ & L. minor and W. arrhiza & $\begin{array}{l}\mathrm{pH} 7.1 / 50 \mu \mathrm{mol} \mathrm{m} \mathrm{m}^{-2} \mathrm{~s}^{-1} / 25 \pm 0.5^{\circ} \mathrm{C} \\
/ 1 \text { week }\end{array}$ & {$[150]$} \\
\hline $2.5 \mathrm{~L}$ & Plastic vessel (3 L) & 1/2 Hoagland & L. gibba & $\begin{array}{l}\mathrm{pH} 6.0-7.0 / \text { outdoor light (Sde Boker, } \\
\text { Israel) } / 25 \pm 6{ }^{\circ} \mathrm{C}\end{array}$ & {$[11]$} \\
\hline $10 \mathrm{~L}$ & $\begin{array}{l}\text { Polyethylene container } \\
(45 \times 30 \times 20 \mathrm{~cm})\end{array}$ & Modified Hoagland & S. intermedia & $\mathrm{pH} 6.5 / 250 \mu \mathrm{mol} \mathrm{m}{ }^{-2} \mathrm{~s}^{-1} / 25 \pm 2^{\circ} \mathrm{C}$ & {$[83]$} \\
\hline $320 \times 10^{1} \mathrm{~L}$ & $\begin{array}{l}\text { Polyethylene mesocosm } \\
(2 \times 4 \times 0.4 \mathrm{~m})\end{array}$ & $\begin{array}{l}\text { Natural drainage water or } \\
\text { underground water }\end{array}$ & L.gibba & $\mathrm{pH} 5-9 /$ outdoor light/ $25-35^{\circ} \mathrm{C}$ & {$[73]$} \\
\hline $126 \mathrm{~L}$ and $100 \times 10^{3} \mathrm{~L}$ & $\begin{array}{l}\text { Cemented outdoor tank } \\
(1.2 \times 0.35 \times 0.3 \mathrm{~m}) \text { or } \\
\text { cemented pond } \\
(20 \times 10 \times 0.5 \mathrm{~m})\end{array}$ & $\begin{array}{l}\text { Organic manure and } \\
\text { inorganic fertilizer }\end{array}$ & S. polyrrhiza & $\begin{array}{l}\mathrm{pH} 6.98-7.91 \text { or } \mathrm{pH} 7.76- \\
8.30 / 26.0 \mu \mathrm{mol} \mathrm{m}{ }^{-2} \mathrm{~s}^{-1} / 9.4-26.7^{\circ} \mathrm{C} \text { or } \\
30.5-33.0^{\circ} \mathrm{C} / 10 \text { days }\end{array}$ & {$[54]$} \\
\hline $180 \times 10^{3} \mathrm{~L}$ & $\begin{array}{l}\text { Outdoor pond } \\
\left(300 \mathrm{~m}^{2} \times 0.6 \mathrm{~m}\right)\end{array}$ & $\begin{array}{l}\text { Pig effluent lagoon or well } \\
\text { water }\end{array}$ & S. polyrrhiza & $\begin{array}{l}\mathrm{pH} 8.4 \text { or } \\
7.2 / 2.89 \mathrm{mmol} \mathrm{m}^{-2} \mathrm{~s}^{-1} / 20-30^{\circ} \mathrm{C}\end{array}$ & {$[106]$} \\
\hline $7620 \times 10^{3} \mathrm{~L}$ & $\begin{array}{l}\text { Artificially designed pond } \\
(518 \times 12 \times 0.3 \mathrm{~m})\end{array}$ & $\begin{array}{l}\text { Ground water, surface } \\
\text { water, and well water }\end{array}$ & Lemna spp. & $\begin{array}{l}\text { Direct or indirect sunlight (Florida, } \\
\text { United States) }\end{array}$ & {$[37,162]$} \\
\hline
\end{tabular}

SH medium used was Schenk and Hildebrandt [144]. MS medium was Murashige and Skoog [146]

$1 / 2$ indicates half-strength of culture medium. Parentheses in the culture scale indicate the volume or size of the vessels

L. Lemna, S. Spirodela, W. Wolffia

the Internet of Things (IoT) and artificial intelligence (AI) technology enables the mass-production of goodquality plants by controlling environmental conditions, such as irrigation irradiation, atmospheric pressure, wind speed, temperature, and humidity $[159,160]$. Aquaponics coupled with IoT and AI technology could be employed for duckweed cultivation in the future. 


\section{Abbreviations}

L.: Lemna; S.: Spirodela; W.: Wolffia; WHO: World Health Organization; LEX System: Lemna Expression System; loT: Internet of Things; Al: Artificial intelligence.

\section{Acknowledgements}

Not applicable.

\section{Authors' contributions}

GB contributed to investigation and writing the manuscript. MS contributed to the investigation. HC contributed to the conceptualization, supervision, and writing the manuscript. All authors have read and approved the final manuscript.

\section{Funding}

This work was supported by the National Research Foundation of Korea (NRF) Grant (NRF-2015R1A5A1008958) funded by the Korean government (MSIP) and Chung-Ang University Research Scholarship Grants in 2020.

\section{Availability of data and materials}

Not applicable.

\section{Declarations}

\section{Competing interests}

The authors declare that they have no competing interests.

Received: 4 August 2021 Accepted: 8 October 2021

Published online: 19 October 2021

\section{References}

1. Les DH, Crawford DJ, Landolt E, Gabel JD, Kimball RT (2002) Phylogeny and systematics of Lemnaceae, the duckweed family. Syst Bot 27:221-240

2. Fu L, Tan D, Sun X, Ding Z, Zhang J (2020) Transcriptional analysis reveals potential genes and regulatory networks involved in salicylic acid-induced flowering in duckweed (Lemna gibba). Plant Physiol Biochem 155:512-522

3. Mbagwu IG, Adeniji HA (1988) The nutritional content of duckweed (Lemna paucicostata Hegelm.) in the Kainji lake area, Nigeria. Aquat Bot 29:357-366

4. Ziegler P, Adelmann K, Zimmer S, Schmidt C, Appenroth KJ (2015) Relative in vitro growth rates of duckweeds (Lemnaceae) - the most rapidly growing higher plants. Plant Biol 17:33-41

5. Wang W (1990) Literature review on duckweed toxicity testing. Environ Res 52:7-22

6. Leng RA, Stambolie JH, Bell R (1995) Duckweed_a potential highprotein feed resource for domestic animals and fish. Livest Res Rural Dev 7:36

7. Culley DD, Epps EA (1973) Use of duckweed for waste treatment and animal feed. J Water Pollut Control Fed 45:337-347

8. Bergmann BA, Cheng J, Classen J, Stomp AM (2000) In vitro selection of duckweed geographical isolates for potential use in swine lagoon effluent renovation. Bioresour Technol 73:13-20

9. Appenroth KJ, Sree KS, Böhm V, Hammann S, Vetter W, Leiterer M, Jahreis $G$ (2017) Nutritional value of duckweeds (Lemnaceae) as human food. Food Chem 217:266-273

10. Shen N, Wang Q, Zhu J, Qin Y, Liao S, Li Y, Zhu Q, Jin Y, Du L, Huang R (2016) Succinic acid production from duckweed (Landoltia punctata) hydrolysate by batch fermentation of Actinobacillus succinogenes GXAS137. Bioresour Technol 211:307-312

11. Del-Campo Marín CM, Oron G (2007) Boron removal by the duckweed Lemna gibba: a potential method for the remediation of boron-polluted waters. Water Res 41:4579-4584

12. Bolotova YV (2015) Aquatic plants of the Far East of Russia: a review on their use in medicine, pharmacological activity, Bangladesh. J Med Sci 14:9-13
13. Bog M, Sree KS, Fuchs J, Hoang PTN, Schubert I, Kuever J, Rabenstein A, Paolacci S, Jansen MAK, Appenroth KJ (2020) A taxonomic revision of Lemna sect. Uninerves (Lemnaceae). Taxon 69:56-66

14. Sree KS, Bog M, Appenroth KJ (2016) Taxonomy of duckweeds (Lemnaceae), potential new crop plants, Emirates. J Food Agric 28:291-302

15. Goopy JP, Murray PJ (2003) A review on the role of duckweed in nutrient reclamation and as a source of animal feed. Asian Australas J Anim Sci 16:297-305

16. Appenroth KJ, Borisjuk N, Lam E (2013) Telling duckweed apart: genotyping technologies for the Lemnaceae. Chin J Appl Environ Biol 19:1

17. Kotowska U, Piotrowska A, Isidorova AG, Bajguz A, Isidorov VA (2013) Gas chromatographic-mass spectrometric investigation of the chemical composition of the aquatic plant Wolffia arrhiza (Lemnaceae). Oceanol Hydrobiol Stud 42:181-187

18. Les DH, Crawford DJ (1999) Landoltia (Lemnaceae), a new genus of duckweeds. Novon 9:530-533

19. Fang YY, Babourina O, Rengel Z, Yang XE, Pu PM (2007) Ammonium and nitrate uptake by the floating plant Landoltia punctata. Ann Bot 99:365-370

20. Lange LD, Westinga $E$ (1979) The distinction between Lemna gibba $L$. and Lemna minor $L$. on the basis of vegetative characters. Acta Bot Neerl 28:169-176

21. Michael TP, Bryant D, Gutierrez R, Borisjuk N, Chu P, Zhang H, Xia J, Zhou J, Peng H, Baidouri ME, Hallers BT, Hastie AR, Liang T, Acosta K, Gilbert S, McEntee C, Jackson SA, Mockler TC, Zhang W, Lam E (2017) Comprehensive definition of genome features in Spirodela polyrhiza by highdepth physical mapping and short-read DNA sequencing strategies. Plant J 89:617-635

22. Lemon GD, Posluszny U, Husband BC (2001) Potential and realized rates of vegetative reproduction in Spirodela polyrhiza, Lemna minor, and Wolffia borealis. Aquat Bot 70:79-87

23. Crawford DJ, Landolt E, Les DH, Tepe E (1997) Allozyme variation and the taxonomy of Wolffiella. Aquat Bot 58:43-54

24. Avci U, Peña MJ, O'Neill MA (2018) Changes in the abundance of cell wall apiogalacturonan and xylogalacturonan and conservation of rhamnogalacturonan II structure during the diversification of the Lemnoideae. Planta 247:953-971

25. Cheng JJ, Stomp AM (2009) Growing duckweed to recover nutrients from wastewaters and for production of fuel ethanol and animal feed. Clean Soil Air Water 37:17-26

26. Mwale M, Gwaze FR (2013) Characteristics of duckweed and its potential as feed source for chickens reared for meat production: a review. Sci Res Essays 8:689-697

27. Ibrahim WM, Eid A, Mohamed K, Abd-elfattah B (2017) Effect of replacement of soybean meal with duckweed (Lemna minor) meal on the growth performance and feed utilization in Nile tilapia fingerlings. $J$ Anim Poult Fish Prod 6:7-12

28. Negesse T, Makkar HPS, Becker K (2009) Nutritive value of some nonconventional feed resources of Ethiopia determined by chemical analyses and an in vitro gas method. Anim Feed Sci Technol 154:204-217

29. Kaplan A, Zelicha H, Tsaban G, Meri AY, Rinott E, Kovsan J, Novack L, Thiery J, Ceglarek U, Burkhardt R, Willenberg A, Tirosh A, Cabantchik I, Stampfer MJ, Shai I (2019) Protein bioavailability of Wolffia globosa duckweed, a novel aquatic plant-a randomized controlled trial. Clin Nutr 38:2576-2582

30. Dewanji A (1993) Amino acid composition of leaf proteins extracted from some aquatic weeds. J Agric Food Chem 41:1232-1236

31. Zhao H, Appenroth K, Landesman L, Salmeán AA, Lam E (2012) Duckweed rising at Chengdu: summary of the 1st international conference on duckweed application and research. Plant Mol Biol 78:627-632

32. Yan Y, Candreva J, Shi H, Ernst E, Martienssen R, Schwender J, Shanklin $J$ (2013) Survey of the total fatty acid and triacylglycerol composition and content of 30 duckweed species and cloning of a $\Delta 6$-desaturase responsible for the production of $\gamma$-linolenic and stearidonic acids in Lemna gibba. BMC Plant Biol 13:201

33. Chalvon-Demersay T, Azzout-Marniche D, Arfsten J, Egli L, Gaudichon C, Karagounis LG, Tome D (2017) A systematic review of the effects of plant compared with animal protein sources on features of metabolic syndrome. J Nutr 147:281-292 
34. Yokoyama Y, Barnard ND, Levin SM, Watanable M (2014) Vegetarian diets and glycemic control in diabetes: a systematic review and metaanalysis. Cardiovasc Diagn Ther 4:373-382

35. de Beukelaar MFA, Zeinstra GG, Mes JJ, Fischer ARH (2019) Duckweed as human food. The influence of meal context and information on duckweed acceptability of Dutch consumers. Food Qual Prefer 71:76-86

36. Bhanthumnavin K, Mcgarry MG (1971) Wolffia arrhiza as a possible source of inexpensive protein. Nature 232:495

37. Olivier L, Havemann G, Antalik P, Alderson B (2017) Method and system for processing of aquatic species. US Patent 9,765,112 B2 19 Sept 2017

38. Parabel Ltd (2021) https://www.parabel.com/lentein/. Accessed 3 Jan 2021

39. van der Spiegel M, Noordam MY, van der Fels-Klerx HJ (2013) Safety of novel protein sources (insects, microalgae, seaweed, duckweed, and rapeseed) and legislative aspects for their application in food and feed production. Compr Rev Food Sci Food Saf 12:662-678

40. González AD, Frostell B, Carlsson-Kanyama A (2011) Protein efficiency per unit energy and per unit greenhouse gas emissions: potential contribution of diet choices to climate change mitigation. Food Policy 36:562-570

41. Meir AY, Tsaban G, Zelicha H, Rinott E, Kaplan A, Youngster I, Rudich A, Shelef I, Tirosh A, Brikner D, Pupkin E, Sarusi B, Blüher M, Stümvoll M, Thiery J, Ceglarek U, Stampfer MJ, Shai I (2019) A green-mediterranean diet, supplemented with mankai duckweed, preserves iron-homeostasis in humans and is efficient in reversal of anemia in rats. J Nutr 149:1004-1011

42. Ifie I, Olatunde S, Ogbon O, Umukoro JE (2021) Processing techniques on phytochemical content, proximate composition, and toxic components in duckweed. Int J Veg Sci 27:294-302

43. WHO, Fao, UNU (2007) Protein and amino acid requirements in human nutrition. HO/FAO/UNU expert consultation. WHO, Genova

44. Al-Snafi AE (2019) Lemna minor : traditional uses, chemical constituents and pharmacological effects-a review. IOSR J Pharm 9:6-11

45. Li J, Lens PNL, Otero-Gonzalez L, Laing GD (2020) Production of selenium- and zinc-enriched Lemna and Azolla as potential micronutrientenriched bioproducts. Water Res. 172:115522

46. Fasakin EA, Balogun AM, Fagbenro OA (2001) Evaluation of sun-dried water fern, Azolla africana, and duckweed, Spirodela polyrrhiza in practical diets for Nile tilapia, Oreochromis niloticus fingerlings. J Appl Aquac 11:83-92

47. Hassan MS, Edwards P (1992) Evaluation of duckweed (Lemna perpusilla and Spirodela polyrrhiza) as feed for Nile tilapia (Oreochromis niloticus). Aquaculture 104:315-326

48. Huque KS, Chowdhury SA, Kibria SS (1996) Study on the potentiality of duckweeds as a feed for cattle. Asian Australas J Anim Sci 9:133-137

49. Damry JVN, Bell RE, Thomson ES (2001) Duckweed as a protein source for fine-wool merino sheep; its edibility and effects on wool yield and characteristics. Asian Australas J Anim Sci 14:507-514

50. Men BX, Ogle B, Lindberg JE (2001) Use of duckweed as a protein supplement for growing ducks. Asian Australas J Anim Sci 14:1741-1746

51. Tallentire CW, Mackenzie SG, Kyriazakis I (2018) Can novel ingredients replace soybeans and reduce the environmental burdens of European livestock systems in the future? J Clean Prod 187:338-347

52. Aslam S, Zuberi A (2017) Effect of duckweed by replacing soybean in fish feed on growth performance of Grass carp (Ctenopharyngodon idella) and Silver carp (Hypophthalmichthys molitrix). Int J Fish Aquat Stud 5:278-282

53. Castanheira ÉG, Freire F (2013) Greenhouse gas assessment of soybean production: implications of land use change and different cultivation systems. J Clean Prod 54:49-60

54. Sharma JG, Clark WD, Shrivastav AK, Goswami RK, Tocher DR, Chakrabarti R (2019) Production potential of greater duckweed Spirodela polyrhiza (L. Schleiden) and its biochemical composition evaluation. Aquaculture 513:734419

55. Ahn YS, Seong NS, Ham IH, Choi HY (2004) Study on the effect of medicinal herbs used as Bu-pyung (S. polyrhiza and L. paucicostata) on immune and anti-cancer. Kor J Herbol 19:117-127

56. González-Renteria M, Monroy-Dosta MDC, Guzmán-García X, Hernández-Calderas I, Ramos-Lopez YMA (2020) Antibacterial activity of Lemna minor extracts against Pseudomonas fluorescens and safety evaluation in a zebrafish model. Saudi J Biol Sci 27:3465-3473
57. Mane VS, Gupta A, Pendharkar N, Shinde B (2017) Exploration of primary metabolites from Lemna minor and determined its immunomodulatory and antimicrobial activity. Eur J Pharm Med Res 4:384-388

58. Das BK, Das DP, Pradhan J, Priyadarshinee B, Sahu I, Roy P, Mishra BK (2012) Evaluation of antimicrobial activity and phytochemical screening of ethanolic extract of greater duckweed, Spirodela polyrrhiza. Int J Pharma Bio Sci 3:822-833

59. Pagliuso D, Palacios Jara CE, Grandis A, Lam E, Pena Ferreira MJ, Buckeridge MS (2020) Flavonoids from duckweeds: potential applications in the human diet. RSC Adv 10:44981-44988

60. Sharma SS, Gupta A, Mane VS, Shinde B (2017) Immunopharmacological activity of flavonoids from Lemna minor (duckweed) and determined its immunological activity. Curr Life Sci 3:22-27

61. Kim J, Lee I, Seo J, Jung M, Kim Y, Yim N, Bae K (2010) Vitexin, orientin and other flavonoids from Spirodela polyrhiza inhibit adipogenesis in 3T3-L1 cells. Phyther Res 24:1543-1548

62. Brown WY, Choct M, Pluske JR (2013) Duckweed (Landoltia punctata) in dog diets decreases digestibility but improves stool consistency. Anim Prod Sci 53:1188-1194

63. Woodard SL, Wilken LR, Barros GOF, White SG, Nikolov ZL (2009) Evaluation of monoclonal antibody and phenolic extraction from transgenic Lemna for purification process development. Biotechnol Bioeng 104:562-571

64. Cox KM, Sterling JD, Regan JT, Gasdaska JR, Frantz KK, Peele CG, Black A, Passmore D, Moldovan-Loomis C, Srinivasan M, Cuison S, Cardarelli PM, Dickey LF (2006) Glycan optimization of a human monoclonal antibody in the aquatic plant Lemna minor. Nat Biotechnol 24:1591-1597

65. Khvatkov P, Firsov A, Shvedova A, Shaloiko L, Kozlov O, Chernobrovkina M, Pushin A, Tarasenko I, Chaban I, Dolgov S (2018) Development of Wolffia arrhiza as a producer for recombinant human granulocyte colony-stimulating factor. Front Chem 6:304

66. Firsov A, Tarasenko I, Mitiouchkina T, Shaloiko L, Kozlov O, Vinokurov L, Rasskazova E, Murashev A, Vainstein A, Dolgov S (2018) Expression and immunogenicity of M2e peptide of avian influenza virus $\mathrm{H} 5 \mathrm{~N} 1$ fused to ricin toxin B chain produced in duckweed plants. Front Chem 6:22

67. Yusibov V, Kushnir N, Streatfield SJ (2016) Antibody production in plants and green algae. Annu Rev Plant Biol 67:669-701

68. Stoger E, Fischer R, Moloney M, Ma JKC (2014) Plant molecular pharming for the treatment of chronic and infectious diseases. Annu Rev Plant Biol 65:743-768

69. Effiong BN, Sanni A (2009) Antifungal properties and phytochemical screening of crude extract of Lemna pauciscostata (Helgelm) against fish feed spoilage fungi. Life Sci J 6:19-22

70. Ceschin S, Crescenzi M, lannelli MA (2020) Phytoremediation potential of the duckweeds Lemna minuta and Lemna minor to remove nutrients from treated waters. Environ Sci Pollut Res 27:15806-15814

71. Farrell JB (2012) Duckweed uptake of phosphorus and five pharmaceuticals: microcosm and wastewater lagoon studies. Dissertation, Utah State University

72. Oron G, de-Vegt A, Porath D, (1988) Nitrogen removal and conversion by duckweed grown on waste-water. Water Res 22:179-184

73. Nafea EMA (2016) Characterization of environmental conditions required for production of livestock and fish fodder from duckweed (Lemna gibba L.). J Mediterr Ecol 14:5-11

74. Türker OC, Baran T (2018) A combination method based on chitosan adsorption and duckweed (Lemna gibba L.) phytoremediation for boron (B) removal from drinking water. Int J Phytoremediation 20:175-183

75. Pagliuso D, Grandis A, Igarashi ES, Lam E, Buckeridge MS (2018) Correlation of apiose levels and growth rates in duckweeds. Front Chem 6:291

76. Verma R, Suthar S (2014) Synchronized urban wastewater treatment and biomass production using duckweed Lemna gibba L. Ecol Eng 64:337-343

77. Teixeira S, Vieira MN, Marques JE, Pereira R (2014) Bioremediation of an iron-rich mine effluent by Lemna minor. Int J Phytoremediation 16:1228-1240

78. Sharma R, Kaur R (2017) Fluoride mediated biochemical responses and removal potential in hydroponically grown duckweed (Spirodela polyrhiza L. scheldien). J Pharm Sci Res 9:2072-2078 
79. Stadtlander T, Förster S, Rosskothen D, Leiber F (2019) Slurry-grown duckweed (Spirodela polyrhiza) as a means to recycle nitrogen into feed for rainbow trout fry. J Clean Prod 228:86-93

80. Cheng J, Bergmann BA, Classen JJ, Stomp AM, Howard JW (2002) Nutrient recovery from swine lagoon water by Spirodela punctata. Bioresour Technol 81:81-85

81. Sutton DL, Ornes WH (1977) Growth of Spirodela polyrhiza in static sewage effluent. Aquat Bot 3:231-237

82. Zhao Y, Fang Y, Jin Y, Huang J, Bao S, Fu T, He Z, Wang F, Zhao H (2014) Potential of duckweed in the conversion of wastewater nutrients to valuable biomass: a pilot-scale comparison with water hyacinth. Bioresour Technol 163:82-91

83. da-Silva CJ, Canatto RA, Cardoso AA, Ribeiro C, Oliveira JA (2017) Arsenic-hyperaccumulation and antioxidant system in the aquatic macrophyte Spirodela intermedia W. Koch (Lemnaceae). Theor Exp Plant Physiol 29:203-213

84. Khellaf N, Zerdaoui M (2010) Growth response of the duckweed Lemna gibba L. to copper and nickel phytoaccumulation. Ecotoxicology 19:1363-1368

85. Zhou Q, Li X, Lin Y, Yang C, Tang W, Wu S, Li D, Lou W (2019) Effects of copper ions on removal of nutrients from swine wastewater and on release of dissolved organic matter in duckweed systems. Water Res 158:171-181

86. Tang Y, Chen L, Wei X, Yao Q, Li T (2013) Removal of lead ions from aqueous solution by the dried aquatic plant, Lemna perpusilla Torr. J Hazard Mater 244-245:603-612

87. Leão GA, de Oliveira JA, Felipe RTA, Farnese FS, Gusman GS (2014) Anthocyanins, thiols, and antioxidant scavenging enzymes are involved in Lemna gibba tolerance to arsenic. J Plant Interact 9:143-151

88. Ritchie RJ, Mekjinda N (2016) Arsenic toxicity in the water weed Wolffia arrhiza measured using Pulse Amplitude Modulation Fluorometry (PAM) measurements of photosynthesis. Ecotoxicol Environ Saf 132:178-185

89. de Souza TD, Borges AC, Braga AF, Veloso RW, de Matos AT (2019) Phytoremediation of arsenic-contaminated water by Lemna valdiviana: an optimization study. Chemosphere 234:402-408

90. Abadi SAH, Baharlouei J, Najafi P, Ghahsareh AM (2020) An assessment of the effect of Lemna minor, Cyanobacteria Oscillatoria Sp and aeration on the elimination of cadmium, nickel and zinc from urban and industrial wastewater. Int J Environ Anal Chem. https://doi.org/10.1080/ 03067319.2020 .1724983

91. Hou W, Chen X, Song G, Wang Q, Chang CC (2007) Effects of copper and cadmium on heavy metal polluted waterbody restoration by duckweed (Lemna minor). Plant Physiol Biochem 45:62-69

92. Prasad MNV, Malec P, Waloszek A, Bojko M, Strzalka K (2001) Physiological responses of Lemna trisulca L. (duckweed) to cadmium and copper bioaccumulation. Plant Sci 161:881-889

93. Bala R, Thukral AK (2011) Phytoremediation of CR(VI) by Spirodela polyrrhiza (L.) schleiden employing reducing and chelating agents. Int J Phytoremediation 13:465-491

94. Guo L, Ding Y, Xu Y, Li Z, Jin Y, He K, Fang Y, Zhao H (2017) Responses of Landoltia punctata to cobalt and nickel: removal, growth, photosynthesis, antioxidant system and starch metabolism. Aquat Toxicol 190:87-93

95. Gatidou G, Oursouzidou M, Stefanatou A, Stasinakis AS (2017) Removal mechanisms of benzotriazoles in duckweed Lemna minor wastewater treatment systems. Sci Total Environ 596-597:12-17

96. Muerdter CP, Lefevre GH (2019) Synergistic Lemna duckweed and microbial transformation of imidacloprid and thiacloprid neonicotinoids. Environ Sci Technol Lett 6:761-767

97. Pietrini F, Di Baccio D, Aceña J, Pérez S, Barceló D, Zacchini M (2015) Ibuprofen exposure in Lemna gibba L.: evaluation of growth and phytotoxic indicators, detection of ibuprofen and identification of its metabolites in plant and in the medium. J Hazard Mater 300:189-193

98. Topal M, Öbek E, Şenel GU, Topal ElA (2020) Removal of tetracycline antibiotic by Lemna gibba L. from aqueous solutions. Water Environ J 34:37-44

99. Iatrou El, Gatidou G, Damalas D, Thomaidis NS, Stasinakis AS (2017) Fate of antimicrobials in duckweed Lemna minor wastewater treatment systems. J Hazard Mater 330:116-126

100. Walsh É, Paolacci S, Burnell G, Jansen MAK (2020) The importance of the calcium-to-magnesium ratio for phytoremediation of dairy industry wastewater using the aquatic plant Lemna minor L. Int J Phytoremediation 22:694-702

101. Ekperusi AO, Nwachukwu EO, Sikoki FD (2020) Assessing and modelling the efficacy of Lemna paucicostata for the phytoremediation of petroleum hydrocarbons in crude oil-contaminated wetlands. Sci Rep 10:8489

102. Imron MF, Kurniawan SB, Soegianto A, Wahyudianto FE (2019) Phytoremediation of methylene blue using duckweed (Lemna minor). Heliyon 5:e02206

103. Su H, Zhao Y, Jiang J, Lu Q, Li Q, Luo Y, Zhao H, Wang M (2014) Use of duckweed (Landoltia punctata) as a fermentation substrate for the production of higher alcohols as biofuels. Energy Fuels 28:3206-3216

104. Zhao X, Elliston A, Collins SRA, Moates GK, Coleman MJ, Waldron KW (2012) Enzymatic saccharification of duckweed (Lemna minor) biomass without thermophysical pretreatment. Biomass Bioenergy 47:354-361

105. Ma YB, Zhu M, Yu CJ, Wang Y, Liu Y, Li ML, Sun D, Zhao JS, Zhou GK (2018) Large-scale screening and characterisation of Lemna aequinoctialis and Spirodela polyrhiza strains for starch production. Plant Biol 20:357-364

106. Xu J, Cui W, Cheng JJ, Stomp AM (2011) Production of high-starch duckweed and its conversion to bioethanol. Biosyst Eng 110:67-72

107. Kurepa J, Shull TE, Smalle JA (2018) Cytokinin-induced growth in the duckweeds Lemna gibba and Spirodela polyrhiza. Plant Growth Regul 86:477-486

108. Muradov N, Fidalgo B, Gujar AC, Garceau N, T-Raissi A (2012) Production and characterization of Lemna minor bio-char and its catalytic application for biogas reforming. Biomass Bioenergy 42:123-131

109. Sowinski EE, Gilbert S, Lam E, Carpita NC (2019) Linkage structure of cell-wall polysaccharides from three duckweed species. Carbohydr Polym 223:115119

110. Hubenova Y, Mitov M (2012) Conversion of solar energy into electricity by using duckweed in direct photosynthetic plant fuel cell. Bioelectrochemistry 87:185-191

111. Yuan J, Xu K (2017) Effects of simulated microgravity on the performance of the duckweeds Lemna aequinoctialis and Wolffia globosa. Aquat Bot 137:65-71

112. Stewart JJ, Adams WW, Escobar CM, López-Pozo M, Demmig-Adams B (2020) Growth and essential carotenoid micronutrients in Lemna gibba as a function of growth light intensity. Front Plant Sci 11:480

113. Bluem V, Paris F (2001) Aquatic food production modules in bioregenerative life support systems based on higher plants. Adv Sp Res 27:1513-1522

114. Shen M, Song B, Zeng G, Zhang Y, Huang W, Wen X, Tamg W (2020) Are biodegradable plastics a promising solution to solve the global plastic pollution? Environ Pollut 263:114469

115. Zeller MA, Hunt R, Sharma S (2013) Sustainable bioderived polymeric materials and thermoplastic blends made from floating aquatic macrophytes such as "duckweed." J Appl Polym Sci 127:375-386

116. Ruekaewma N, Piyatiratitivorakul S, Powtongsook S (2015) Culture system for Wolffia globosa L. (Lemnaceae) for hygiene human food. Songklanakarin J Sci Technol 37:575-580

117. Verma R, Suthar S (2016) Bioenergy potential of duckweed (Lemna gibba L.) biomass. Energy Sources Part A Recover Util Environ Eff 38:2231-2237

118. Rusoff LL, Blakeney EW, Culley DD (1980) Duckweeds (Lemnaceae family): a potential source of protein and amino acids. J Agric Food Chem 28:848-850

119. Tang J, Li Y, Ma J, Cheng JJ (2015) Survey of duckweed diversity in Lake Chao and total fatty acid, triacylglycerol, profiles of representative strains. Plant Biol 17:1066-1072

120. Aguilera-Morales ME, Canales-Martínez MM, Ávila-González E, FloresOrtíz CM (2018) Nutrients and bioactive compounds of the Lemna gibba and Ulva lactuca as possible ingredients to functional foods. Lat Am J Aquat Res 46:709-716

121. Yu G, Liu H, Venkateshan K, Yan S, Cheng J, Sum XS, Wang D (2011) Functional, physiochemical, and rheological properties of duckweed (Spirodela polyrhiza) protein. Trans ASABE 54:555-561

122. Zhang X, Chen H, Wu D, Gu W, Sun W, Chen J, Wu Q (2018) Determination of free amino acids in three species of duckweed (Lemnaceae). J Food Qual. https://doi.org/10.1155/2018/7673652 
123. Zhao X, Moates GK, Wellner N, Collins SRA, Coleman MJ, Waldron KW (2014) Chemical characterisation and analysis of the cell wall polysaccharides of duckweed (Lemna minor). Carbohydr Polym 111:410-418

124. Vladimirova IN, Georgiyants VA (2014) Biologically active compounds from Lemna minor S. F. Gray. Pharm Chem J 47:599-601

125. Sree KS, Adelmann K, Garcia C, Lam E, Appenroth KJ (2015) Natural variance in salt tolerance and induction of starch accumulation in duckweeds. Planta 241:1395-1404

126. Saini RK, Keum YS (2018) Omega-3 and omega-6 polyunsaturated fatty acids: dietary sources, metabolism, and significance - a review. Life Sci 203:255-267

127. Park J, Kim M, Kang SG, Jannasch AH, Cooper B, Patterson J, Kim CH (2015) Short-chain fatty acids induce both effector and regulatory $T$ cells by suppression of histone deacetylases and regulation of the mTOR-S6K pathway. Mucosal Immunol 8:80-93

128. Ríos-Covián D, Ruas-Madiedo P, Margolles A, Gueimonde M, DE los Reyes-Gavilán CG, Salazar N (2016) Intestinal short chain fatty acids and their link with diet and human health. Front Microbiol 7:185

129. Sakihama Y, Cohen MF, Grace SC, Yamasaki H (2002) Plant phenolic antioxidant and prooxidant activities: phenolics-induced oxidative damage mediated by metals in plants. Toxicology 177:67-80

130. Zhao Y, Fang Y, Jin Y, Huang J, Bao S, Fu T, He Z, Wang F, Wang M, Zhao $H$ (2015) Pilot-scale comparison of four duckweed strains from different genera for potential application in nutrient recovery from wastewater and valuable biomass production. Plant Biol 17:82-90

131. Qiao X, He WN, Xiang C, Han J, Wu L, Guo E, Ye M (2011) Qualitative and quantitative analyses of flavonoids in Spirodela polyrrhiza by highperformance liquid chromatography coupled with mass spectrometry. Phytochem Anal 22:475-483

132. Bai HH, Wang NN, Mi J, Yang T, Fang DM, Wu LW, Zhao H, Li GY (2018) Hydroxycinnamoylmalated flavone C-glycosides from Lemna japonica. Fitoterapia 124:211-216

133. Kim JY, Kim HY, Jeon JY, Kim DM, Zhou Y, Lee JS, Lee H, Choi HK (2017) Effects of coronatine elicitation on growth and metabolic profiles of Lemna paucicostata culture. PLOS ONE 12:e0187622

134. Borisjuk N, Peterson AA, Lv J, Qu G, Luo Q, Shi L, Chen G, Kishchenko O, Zhou Y, Shi J (2018) Structural and biochemical properties of duckweed surface cuticle. Front Chem 6:317

135. Coman V, Vodnar DC (2020) Hydroxycinnamic acids and human health: recent advances. J Sci Food Agric 100:483-499

136. Taofiq O, González-Paramás AM, Barreiro MF, Ferreira ICFR (2017) Hydroxycinnamic acids and their derivatives: cosmeceutical significance, challenges and future perspectives, a review. Molecules 22:281

137. Bohlmann J, Keeling Cl (2008) Terpenoid biomaterials. Plant J 54:656-669

138. Zhao YC, Xue CH, Zhang TT, Wang YM (2018) Saponins from sea cucumber and their biological activities. J Agric Food Chem 66:7222-7237

139. Kritchevsky D, Chen SC (2005) Phytosterols - health benefits and potential concerns: a review. Nutr Res 25:413-428

140. Ankutowicz EJ, Laird RA (2018) Offspring of older parents are smallerbut no less bilaterally symmetrical — than offspring of younger parents in the aquatic plant Lemna turionifera. Ecol Evol 8:679-687

141. Paolacci S, Harrison S, Jansen MAK (2018) The invasive duckweed Lemna minuta Kunth displays a different light utilisation strategy than native Lemna minor Linnaeus. Aquat Bot 146:8-14

142. Utami D, Kawahata A, Sugawara M, Jog RN, Miwa K, Morikawa M (2018) Effect of exogenous general plant growth regulators on the growth of the duckweed Lemna minor. Front Chem 6:251

143. Nas MN, Read PE (2004) A hypothesis for the development of a defined tissue culture medium of higher plants and micropropagation of hazelnuts. Sci Hortic 101:189-200

144. Schenk RU, Hildebrandt AC (1972) Medium and techniques for induction and growth of monocotyledonous and dicotyledonous plant cell cultures. Can J Bot 50:199-204
145. Hutner SH, Provasoli L, Schnatz A, Haskins CP (1950) Some approaches to the study of the role of metals in the metabolism of microorganisms. Proc Am Philos Soc 94:152-170

146. Murashige T, Skoog F (1962) A revised medium for rapid growth and bio assays with tobaocco tissue cultures. Physiol Plant 15:473-497

147. Hogland DR, Arnon DI (1950) The water-culture method for growing plants without soil. Calif Agric Exp Stn 347:25-32

148. Kittiwongwattana C (2019) Differential effects of synthetic media on long-term growth, starch accumulation and transcription of ADPglucosepyrophosphorylase subunit genes in Landoltia punctata. Sci Rep 9:15310

149. Sun Z, Guo W, Yang J, Zhao X, Chen Y, Yao L, Hou H (2020) Enhanced biomass production and pollutant removal by duckweed in mixotrophic conditions. Bioresour Technol 317:124029

150. Kotowska U, Karpinska J, Kapelewska J, Kowejsza EM, Piotrowska-Niczyporuk A, Piekutin J, Kotowski A (2018) Removal of phthalates and other contaminants from municipal wastewater during cultivation of Wolffia arrhiza. Process Saf Environ Prot 120:268-277

151. Chakrabarti R, Clark WD, Sharma JG, Goswami RK, Shrivastav AK, Tocher DR (2018) Mass production of Lemna minor and its amino acid and fatty acid profiles. Front Chem 6:479

152. Kuznetsova T, Politaeva N, Smyatskaya Y, Ivanova A (2019) Lemna minor cultivation for biofuel production. IOP Conf Ser Earth Environ Sci 272:022058

153. Caicedo JR, Van Der Steen NP, Arce O, Gijzen HJ (2000) Effect of total ammonia nitrogen concentration and $\mathrm{pH}$ on growth rates of duckweed (Spirodela polyrrhiza). Water Res 34:3829-3835

154. Ol'shanskaya LN, Politaeva NA, Aref'eva OA, Valiev RS (2018) Intensification of biomass cultivation process of Lemna minor at physical exposure. Nat Environ Pollut Technol 17:619-624

155. Tkalec M, Malarić K, Pevalek-Kozlina B (2007) Exposure to radiofrequency radiation induces oxidative stress in duckweed Lemna minor $\mathrm{L}$. Sci Total Environ 388:78-89

156. Wang W, Messing J (2012) Analysis of ADP-glucose pyrophosphorylase expression during turion formation induced by abscisic acid in Spirodela polyrhiza (greater duckweed). BMC Plant Biol. https://doi.org/ 10.1186/1471-2229-12-5

157. Kuehdorf K, Jetschke G, Ballani L, Appenroth KJ (2014) The clonal dependence of turion formation in the duckweed Spirodela polyrhizaan ecogeographical approach. Physiol Plant 150:46-54

158. Goddek S, Delaide B, Mankasingh U, Ragnarsdottir KV, Jijakli H, Thorarinsdottir R (2015) Challenges of sustainable and commercial aquaponics. Sustainability 7:4199-4224

159. García L, Parra L, Jimenez JM, Lloret J, Lorenz P (2020) loT-based smart irrigation systems: an overview on the recent trends on sensors and iot systems for irrigation in precision agriculture. Sensors 20:1042

160. Adamides G, Kalatzis N, Stylianou A, Marianos N, Chatzipapadopoulos F, Giannakopoulou M, Papadavid G, Vassiliou V, Neocleous D (2020) Smart farming techniques for climate change adaptation in Cyprus. Atmosphere 11:557

161. Stomp AM, Rajbhandari N (2000) Genetically engineered duckweed. US Patent 6,040,498. Accessed 21 Mar 2000

162. Javan A, Grieco W, Cumba HJ, Weaver H, Lovas B (2018) Cultivation, harvesting and processing of floating aquatic species with high growth rates. US Patent 9,894,856. Accessed 20 Feb 2018

\section{Publisher's Note}

Springer Nature remains neutral with regard to jurisdictional claims in published maps and institutional affiliations. 